\title{
Serendipity in the discovery of $T$ cell/B cell cooperation
}

\author{
Henry N. Claman
}

Received: 25 May 2010/Accepted: 25 May 2010/Published online: 9 June 2010

(C) Springer Basel AG 2010

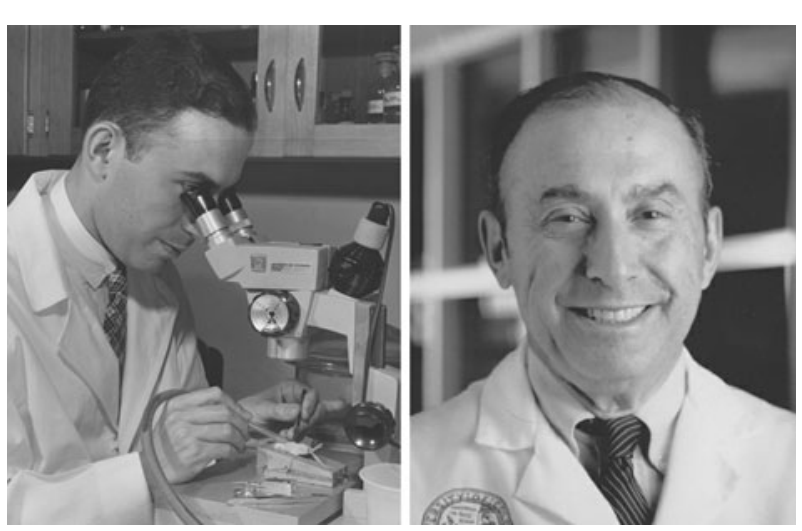

Henry Claman, 1964, thymectomizing a mouse, and today

In 1966, my colleagues and I published a small paper showing that combinations of thymus cells and bone marrow cells (in adoptive transfer experiments in mice) produced more antibodies to sheep red blood cells than either population alone. We called this "thymus-marrow synergism" [1]. It was an unexpected finding.

The pathway I took to get to it was unexpected as well.

I was born in New York City into a medical family (both my parents and one grandfather were practicing physicians). I was fortunate in my schooling, attending The Lincoln School of Teachers College and The Horace Mann School. After Harvard College (where I majored in Philosophy) I went to New York University College of Medicine. In my last year, I spent some time in a research laboratory. Frankly, I did not find it interesting. The

H. N. Claman $(\bowtie)$

Denver, CO, USA

e-mail: henry.claman@ucdenver.edu experience confirmed my desire to practice internal medicine.

After internship and residency at Barnes Hospital (Washington University, St. Louis) and Massachusetts General Hospital, I entered the US Army for 2 years (1959-1961). This was part of "The Berry Plan" for young doctors during the Korean War.

I was posted to Fort George G. Meade, Maryland, between Baltimore and Washington, DC. There I practiced internal medicine. I was also "requested" (i.e., ordered) to set up an Allergy Clinic. I protested (weakly) that I was neither trained nor terribly interested in that field (and did not mention that Mother was a well-know allergist in NYC). But the hospital commander persisted, and I was "trained" in the subspecialty during 10 half-days at Walter Reed Hospital.

I bought a textbook (John Sheldon's) and got to work. For 2 years I ran the clinic- took all the histories, did all the physicals, put on all the skin tests and gave all the shots.

It was a fascinating practice, and it was also an exciting time in immunology. To mention just a few milestones that had been recently passed, Porter and Edelman were unraveling the structure of immunoglobulins, and Talmage and Burnet were elucidating the Clonal Selection Theory of antibody diversity, bringing Darwin right into the immunology laboratory.

At the same time that immunology was intriguing me, internal medicine was not. I thought I should try research again so that if I did not like it, I at least would know that the practice of medicine was where I belonged.

I learned about NIH fellowships and decided to apply for one. Which one? I knew none of the directors. But Carl Moore, Chair of Medicine at Washington University (where I had been), strongly recommended David Talmage 
at the University of Colorado. That was enough, and I arrived in Denver on 1 February 1961. On the first day, Dave showed me how to hold a mouse in one hand and inject it i.p. with the other (and not get bitten). And so I was off and running.

Or rather, off and stumbling. Most of my experiments failed but I was having a great time-in the lab, in the allergy clinic, on the wards as attending, doing allergy consults-it was all stimulating. Dave Talmage was a brilliant lab chief and had gathered a small cadre of colleagues, including Andor Szentivanyi, Charles Fischel and Joseph Ingraham. Post-doctoral fellows included me, Edward P. Cohen, Charles H. Kirkpatrick, W. "Ted" Wilson and others.

At first, I studied antibody formation in rabbits and struggled with the ammonium sulfate precipitation antibody detection system known as "the Farr test."

During this time, there were important developments in our general understanding of the immunologic system. It was recognized that there were "two universes"-the "humoral" world of antibody production and the "cellular" world of delayed hypersensitivity/cell-mediated immunity. Furthermore, the concept that the immune system might be anatomically as well as functionally compartmentalized was growing, particularly after the 1956 fortuitous experiments of Chang and Glick, which showed that early removal of the bursa of Fabricius from the lower GI tract of chickens led to a selective impairment of antibody production.

The functions (if any) of the thymus remained hidden. The main stumbling block was the finding that the removal of this lymphoid organ generally was not followed by evidence of immunologic impairment. The breakthrough came in 1961-1962 with the simultaneous (and independent) publications from Miller in England [2] and Robert A. Good in Minneapolis [3] that thymectomy in the newborn period was followed by impairment in both universes-humoral and cellular. This was news!

A big step forward soon occurred when Bob Good convened a conference on The Thymus in Immunobiology in November 1962 in Minneapolis. (The proceedings were published 2 years later [4]. The volume is well worth consulting because it details the ferment in the field at the time-the progress and the concomitant dissenting opinions.) "Everyone" in the field was there, and it was a stimulating environment even for a second-year postdoc like myself. I met the leaders in the field, particularly Miller, who was to spend two summer stints with us in Denver because of the availability of pregnant opossums, whose newborns could be thymectomized at a very early stage of development.
Dave Talmage and I did experiments on the role of the thymus in adult mice, showing that thymectomy delayed the waning of acquired immunological tolerance to bovine gamma globulin. This suggested the thymus had a role in adult life as well as in the newbon period, by providing a source of immunocompetent lymphocytes capable of terminating the tolerant state once the antigen was gone [5].

The question remained, however, why did not all those thymocytes, if they were indeed imunocompetent, make antibody in immunized adults? Now at that time, there was a question of a blood-thymus barrier, i.e., maybe antigens did not get to thymocytes as they did to spleen (or bursa) lymphocytes. There were some data to support this from Sam Clark, an electron microscopist, whom I knew from St. Louis and who was at the Minneapolis Thymus meeting.

Since there was no method to demonstrate a primary antibody response in vitro, we used the relatively new system of adoptive transfer of lymphoid cells into irradiated syngeneic recipients. The experiments were mainly performed in 1965, with Edward A. Chaperon, Ph.D., a postdoctoral fellow from Harold Wolfe's laboratory at the University of Wisconsin, together with R. F. Triplett, III, M.D. a postdoctoral Pediatric fellow, and Jean Baughman and Terrill Smith, our laboratory technicians.

The rationale was to disrupt any blood-thymus barrier by making single cell suspensions of adult thymus and to adoptively transfer them into syngeneic adult recipients that had just been sublethally irradiated to knock out their own immune system. The recipients would then be injected with the favorite antigen for mice at that time, i.e., sheep erythrocytes (SRBC). This setup was often referred to as an "in vivo tissue culture" preparation. After a few days, hemolytic antibody would be sought in the spleens of the recipients, by techniques pioneered by Jerne [6] and Playfair [7] and colleagues. This was an experimental approach that had previously shown that donor spleen cells plus SRBC would develop into hemolytic antibody-producing cells in irradiated recipient spleens. The amount of antibody was proportional to the number of spleen cells transferred. Thus, spleen cells contained the necessary radiosensitive "machinery" for antibody production in the in vivo tissue culture system.

How would thymus cells do in the same system?

The experimental setup was simple. Recipients were irradiated on day 0 and then injected with saline, or spleen cells or thymus cells. On day 1 , they were all injected with SRBC. On day 5 they were killed, and the recipient spleens were sliced into fragments and plated out in Petri dishes on a lawn of SRBC. Complement was added to complete the hemolytic antibody assay, and the percentage of spleen fragments making hemolytic antibody was scored. 


\begin{tabular}{|c|c|c|c|}
\hline & $\begin{array}{l}\text { Day } 0 \text { (irradiation } \\
\text { and transfer) }\end{array}$ & $\begin{array}{l}\text { Day } 1 \\
\text { (immunize) }\end{array}$ & $\begin{array}{l}\text { Day } 5 \\
\text { (sacrifice) }\end{array}$ \\
\hline A & Saline (neg. control) & SRBC & 0 antibody \\
\hline B & Spleen (pos. control) & SRBC & ++++ antibody \\
\hline $\mathrm{C}$ & Thymus (experimental) & SRBC & \pm antibody \\
\hline
\end{tabular}

Thus, while transferred spleen cells produced antibody, as expected, transferred thymus cells did not. Furthermore, spleen cells from SRBC-immunized donors (not shown) produced more antibody than those from unimmunized mice. With thymus cell suspensions, immunizing the donor made no difference.

Well-a negative experiment. But we were unwilling to stop there and wondered whether the thymus cells were "too immature" to respond adequately in 4 days, and might do better with more antigen and more time in the recipient. Thus, we lengthened the experiment, boosting with SRBC on day 4, with sacrifice on day 8. Trouble ensued!

\begin{tabular}{lllll}
\hline & Day 0 & Day 1 & Day 4 & Day 8 (sacrifice) \\
\hline A & Saline & SRBC & SRBC & Dead recipients! \\
B & Spleen & SRBC & SRBC & ++++ antibody \\
C & Thymus & SRBC & SRBC & Dead recipients! \\
\hline
\end{tabular}

We saw that groups $\mathrm{A}$ and $\mathrm{C}$ had died a hematopoietic death while group B did not, as the spleen is a source of hematopoietic stem cells able to repopulate the lethally irradiated recipient.

Extensive research on hematopoietic reconstitution (an unintended benefit from nuclear experiences) told us what to do. We sought to keep groups $\mathrm{A}$ and $\mathrm{C}$ alive at day 8 by adding syngeneic bone marrow cells, and to our surprise, thymus-plus-bone marrow cell combinations led to antibody production! In fact, they behaved similarly to spleen cell-injected groups.

To clean up the experimental model, we now need no cell (control) groups, and "thymus only" groups, and "bone marrow only" groups and finally "thymus-plusmarrow" groups. To get these, we "fiddled" with x-ray dosages and explored different strains of mice. Finally, we had it figured out. The model experiment now looked like this.

\begin{tabular}{llll}
\hline & Cells injected & Antigen $(\times 2)$ & Hemolytic antibody, day 8 \\
\hline A & Thymus & SRBC & \pm \\
B & Marrow & SRBC & 0 \\
C & Thymus + marrow & SRBC & ++++ \\
D & Spleen & SRBC & ++++ \\
E & None & SRBC & \pm \\
\hline
\end{tabular}

The data seemed convincing-thymus-marrow cell combinations were as immunocompetent as spleen cells, but neither thymus alone nor marrow alone was sufficient. We called the phenomenon thymus-marrow "synergism" or "complementation."

Which cell was making the antibody? We tried a number of experiments, none of which was successful, so we guessed (based on some data of others) that the bone marrow cells made the antibody, and the thymus cells performed an "auxiliary" role (the word "help" was not used by us). We had a $50 \%$ chance, and it turned out that our guess was right. But we had no proof. In fact, we did not realize that our findings would change our understanding of the structure and function of the entire immune system. The results were recognized as important indeed, but it took time for the full ramifications to become apparent. Meanwhile, we did want rapid publication and so picked The Proceedings of the Society for Experimental Biology and Medicine [1]. Soon, the elegant experiments of Miller and Graham Mitchell definitively showed that, yes, the bone marrow cells made the antibody [8].

But the impact grew. An important advance came via applying the thinking of thymus-marrow synergism to "the carrier effect." In this model, animals were immunized with haptens linked to various protein carriers. The production of antibody to the hapten required an immune response to the carrier. It was, I believe, either Richard Gershon of Yale or Avrion Mitchison of University College, London who recognized that it was thymus-derived (T) cells that responded to the carrier and bone marrowderived (B) cells that produced the antibody to the hapten. It was about this time that the $\mathrm{T}$ cells were called "helpers."

For our part, we continued our work in mice, but turned to problems of tolerance. The T-B synergism model was poised for the development of cytokine research, which considerably enhanced our understanding of how $\mathrm{T}$ cells do in fact "help" B cells. Those findings, and the recognition of the importance of antigen-presenting macrophages and dendritic cells [9] completed the initial phases of what can now be seen as the elucidation of both of the immunological universes-of "cellular" immunology, as well as of "humoral" immunology, and how they are interdependent and mutually co-regulatory.

\section{References}

1. Claman HN, Chaperon EA, Triplett RF (1966) Thymus-marrow cell combinations: synergism in antibody production. Proc Soc Exp Biol Med 122:1167-1171

2. Miller JFAP (1961) Immunological functions of the thymus. Lancet 2:748-749 
3. Archer OK, Pierce JC, Papermaster BW, Good RA (1962) Reduced antibody response in thymectomized rabbits. Nature 195:191-193

4. Good RA, Gabrielsen A (eds) (1964) The thymus in immunobiology. Hoeber-Harper, New York

5. Claman HN, Talmage DW (1963) Thymectomy: prolongation of immunological tolerance in the adult mouse. Science 141:11931194

6. Jerne NK, Nordin AA (1963) Plaque formation in agar by single antibody-producing cells. Science 140:405
7. Playfair JHL, Papermaster BW, Cole LJ (1965) Focal antibody production by transferred spleen cells in irradiated mice. Science 149:998-1000

8. Mitchell GF, Miller JFAP (1968) Cell to cell interaction in the immune response. II. The source of hemolysin-forming cells in irradiated mice given bone marrow and thymus or thoracic duct lymphocytes. J Exp Med 128:821-831

9. Mosier DE, Coppleson LW (1968) A three-cell interaction required for the induction of the primary immune response in vitro. Proc Natl Acad Sci USA 61:542-547 